\title{
A Framework for Accessible m-Government Implementation
}

\author{
Maria Emmanouilidou
}

Salford Business School

University of Salford

43 The Crescent

Manchester, M5 4WT, UK

Phone number: 01612952091

Email: M.Emmanouilidou@pgr.salford.ac.uk

David Kreps

Salford Business School

University of Salford

43 The Crescent

Manchester, M5 4WT, UK

Phone number: 01612955884

Email: D.G.Kreps@salford.ac.uk

\begin{abstract}
The great popularity and rapid diffusion of mobile technologies at worldwide level has also been recognized by the public sector, leading to the creation of $\mathrm{m}$-Government. A major challenge for m-Government is accessibility - the provision of an equal service to all citizens irrespective of their psychical, mental or technical capabilities. This paper sketches the profiles of six citizen groups: Visually Impaired, Hearing Impaired, Motor Impaired, Speech Impaired, Cognitive Impaired and Elderly. m-Government examples that target the
\end{abstract}


aforementioned groups are discussed and a framework for accessible m-Government implementation with reference to the W3C Mobile Web Best Practices is proposed.

Keywords: mobile government; electronic government; accessibility; usability; social inclusion; elderly; disabled.

Biographical notes: Maria Emmanouilidou is a $\mathrm{PhD}$ candidate and earned a position of a Graduate Teaching Assistant (GTA) within the Business School at the University of Salford. She holds a BSc in Computer Science from the University of Leeds and an MSc in Advanced Computer Science with ICT (Information and Communication Technologies) Management from the University of Manchester. Her research interests are centred on the areas of strategic IT management, e-Healthcare systems and e-Inclusion with a focus on the usability and accessibility effect of electronic and mobile government and commerce systems to particular populations, such as the elderly and people with disabilities.

Dr. David Kreps is an 'early adopter', pioneering thinker and commentator, with a fascination for technology and its impact upon society, and a background in Cultural Studies and Sociology. A web developer since 1995, he did his PhD thesis on Cyborgism, and has since become an expert on Web Accessibility, and explorer into the philosophy of Virtuality. David was PI on the recent Combating e-Discrimination European Social Fund project, and has published widely in Information Systems journals and conferences on e-Accessibility and Virtuality. David Lectures in Web Development, and Emerging Technologies at the University of Salford. 


\section{Introduction}

Both the internet as a whole, and e-Government (electronic government) in particular, have been the focus of attention for those concerned with ensuring issues of social inclusion are not ignored (for examples see Adam and Kreps, 2006a; Marincu and McMullin, 2004). The World Wide Web, on the face of it, is a great leveller, granting access to information and services to many for whom such access has been difficult in the past. The opportunities of eCommerce have granted small and medium sized enterprises (SMEs) the world over with a shop window on a par with global corporations, and enabled virtual organisations, without the overheads of their corporate cousins, a chance to flourish. Ostensibly, members of any ethnic, gender or minority grouping have equal access to the potential of the web - as long as they can gain access to it. The issue of the digital divide has been much discussed in the literature, between those who have access and those who do not (for examples see Loader, 1998; Marshall et al., 2003; Norris, 2001; Servon, 2002) and raises in importance as governments around the globe become more and more technically savvy (Choudrie et al., 2007). However, there is one group of people for whom the web presents many problems, even if they have a computer or other internet device, and that group is disabled people.

This group is identified among others as a key stakeholder group whose needs should be considered by governments so that they will not be excluded from embracing the opportunities of e-Government (Chircu, 2008). Disabled people use a range of assistive technologies to bridge the gap of their disability: screen readers for the blind and dyslexic, alternative kinds of mouse for those with physical disabilities unable to use the standard interface, and others. The techniques to ensure that web pages are accessible to such assistive devices were developed in the late 1990s, not long after the web itself and have been implemented with mixed success, as discussed elsewhere (Adam and Kreps, 2006b; Kreps, 
2008; Kreps and Adam, 2006). Encouraging web designers to use such techniques has clearly proven very difficult.

In the arena of Public Policy, however, governments have been in a position to take a lead, and have mandated such techniques in public sector websites, as part of the roll-out of eGovernment, since the turn of the millennium. The United States (US) has its Section 508 of the new Rehabilitation Act 1998, mandating specified practices on Federal websites, and the European Union (EU) parliament and commission have made a number of statements mandating the World Wide Web Consortium's Web Content Accessibility Guidelines for eGovernment websites across Europe (Council of Europe, 2003).

UNDPEPA (2002) in Choudrie et al. (2004, p.105) define e-Government as "an internetdriven activity that improves citizen access to government information, services and expertise to ensure citizen participation in and satisfaction with the government process". In general, "e-Government involves the electronic provision of information to geographically diverse but technologically homogeneous ICTs (such as personal computers and information kiosks) in fixed locations" (Carroll, 2006, p.3). In recent years however, there has been a "rapid diffusion of mobile ICTs such as laptops, mobile phones, PDAs (Personal Digital Assistants), pocket PCs, along with emails, instant messaging, and other networking services" (Song and Cornford, 2006, p.208). The availability of such mobile devices has brought increasing pressure to provide access to government services while mobile - to make m-Government (mobile government) versions of e-Government services. Government agencies have therefore begun to adjust their activities to this trend, to make convenient and efficient interactions available for all parties involved (Kushchu and Kuscu, 2003).

Kushchu and Kuscu (2003, p.2) define m-Government as a "strategy and its implementation involving the utilization of all kinds of wireless and mobile technology, services, applications 
and devices for improving benefits to the parties involved in e-Government including citizens, businesses and all government units". In contrast to e-Government, in mGovernment the use contexts are not known and the physical constraints of interacting with mobile devices limit both the amount and type of information that can be located and accessed. Moreover, accessing a government service within a mobile environment is frequently one of several other activities that are undertaken simultaneously. (Carroll, 2006)

Although m-Government is still in its relatively early days, it appears rather promising. mGovernment is expected to be widely embraced, as it promises access to government services at any place and time - a key citizen demand. The real value of such 'anytime-anywhere availability' can be better appreciated, if $\mathrm{m}$-Government is regarded as an effective means for reaching more easily those characterised more broadly as socially excluded. The term socially excluded has a great range of meanings, often depending upon the context. It is used here to refer to people living in rural areas and people from lower income and academic backgrounds that often cannot afford a home computer or lack the skills required for mastering the use of a personal computer. Choudrie et al. (2007) emphasise that apprehensions attributed to social exclusions that can occur due to inequitable ICT dissemination can in turn result in citizens falling under the above mentioned category not having access to information technology. A novel form of digital divide can therefore emerge which can lead to a new dimension of the notion of disability that expands from the traditional physical and mental in nature disability to disability also caused by ethnicity, age or even literacy (Choudrie et al., 2007).

By contrast mobile devices have achieved much greater ubiquity. In the United Kingdom (UK), for example, over 75 per cent of adults had a mobile phone by 2003, and some 56 per cent owned a personal computer by 2006 (Office for National Statistics, 2007). According to 
Comscore (2007), use of the internet over mobile devices in the UK was already a fifth of that over personal computers by May 2007. Across the developed and the developing world access to mobile phones and other wireless devices has surpassed that of PCs (Personal Computers) with internet access. Recent statistics show that mobile phone penetration was expected to reach 61 per cent by the end of 2008 (International Telecommunication Union, 2008) - some 3.6 billion. PC usage worldwide is around 1 billion, which corresponds to about 15 per cent of the global population, with internet penetration projected to reach 20 per cent by year 2008 (Computer Economics, 2007; Meyer, 2008; U.S. Census Bureau, 2008). It is therefore clear that cell phones are far more popular than computers.

Why is this so? For a large proportion of the world's population the use of computers and the internet is not always a trivial task. One user group that may face serious problems with ICTs is the elderly, as a significant proportion of this group - despite the oft trailed 'silver surfers' whose number, though growing, is frequently exaggerated (Kok, 2009) - lack technological capabilities related to internet and PC usage. According to Dwivedi and Williams (2008) older people's unwillingness to engage with ICT (including the internet) can be explained due to their lack of basic skills to operate a computer and lack of possession of a home computer. The result can be that older people may be slow in adopting e-Government services, a fact that is further supported by their frequent unawareness of the potential benefits of e-Government services and new developments (Dwivedi and Williams, 2008). All these are quite apart from the disabilities that come with old age. Interestingly enough, Vincent and Harris (2008) identify mobile phones (and digital television) as possible suitable future routes for the provision of public services in particular to the elderly population.

For the public sector therefore, m-Government appears to be an attractive alternative, as well as adjunct, to e-Government, in particular for the developing world, where internet access 
rates are very low, but mobile phone penetration is growing rapidly (Kumar and Sinha, 2007). Within this context, m-Government could aid in creating more socially inclusive government services. It could be argued that mobile devices with their simplicity and popularity among different populations could provide a solution for overcoming the digital divide barriers imposed by traditional e-Government applications. Nevertheless, mGovernment is unlikely to replace e-Government, but rather constitute a complementary communication channel of e-Government. A recent study by Verdegem and Hauttekeete (2008) in Flanders, Belgium, looking at the potential and added value of new channels, such as digital television and mobile applications, for the delivery of public services, shows people's future intentions for accessing government services remain via the traditional channels of counter, telephone, mail and internet, with the new media neglected or forgotten as potential candidates for interaction with the public sector. Verdegem and Hauttekeete (2008) justify this trend in terms of people's unawareness of the possibilities or functionalities of these new media. It is also possible that the usability and accessibility of mobile phones is a key deciding factor. Thus m-Government may only become a reality if there is a substantial change in both social and technical practices (Vincent and Harris, 2008).

In the arena of Public Policy, we argue, as with e-Government, it is likely that with mGovernment, governments are in a position to take a lead, and should mandate an eAccessibility aware approach to the roll out of m-Government applications and services. Recent work by $\mathrm{Wu}$ et al. (2009) pinpoints as one fundamental challenge for the successful deployment of m-Government how the technology can be accessible in two particular populations, the physically challenged and the aging. Ease of access to m-Government information will be crucial in order to improve citizen participation and promote citizen-oriented services (Wu et al., 2009). The 
aim of this paper is to identify the e-Accessibility challenges that are present for the development of mobile government services, and explore the status of recent mobile government initiatives for disabled users. We propose a framework that addresses the key characteristics and requirements of those citizen groups that may be disadvantaged through disability when interacting with m-Government applications and services.

The paper is structured in the following way: in section two, we introduce some of the specific accessibility challenges for mobile devices, and set out a table of disabled groups and the potential problems they may encounter, and the assistive technologies which may assist them in overcoming such access problems. In section three we identify a number of mGovernment implementations for use by disabled people, and in section four we outline our framework for accessible m-Government implementation.

\section{Accessibility Challenges for Mobile Devices, Disabled People and Assistive Technologies for Mobile Platforms}

The accessibility challenges associated with the use of mobile devices imply that some services may not be suitable for consideration as part of the $\mathrm{m}$-Government agenda. This fact is also apparent in e-Government attempts. Evidence of the UK's government failure to appreciate that some services may not be relevant or desirable for online delivery is shown by Kolsaker and Lee-Kelley (2007). Within the mobile context in particular, the accessibility challenges are intensified by the fact that there are no standard browsers for mobile and wireless devices nor is there a single standard for all wireless devices. Furthermore, wireless devices have different display capabilities that are limited by display size, support for colour and graphics as well as limited input capabilities (for example lack of a full keyboard, buttons, pen-based, etc.) (Sharma and Gupta, 2004). 
Other limitations of mobile devices involve limited computational power and memory, short battery life, higher risk of data storage and transaction errors, lower display resolution, less surfing ability, and unfriendly user-interfaces. Moreover, technical restrictions related to connectivity, such as low bandwidth and limited geographical scope, limit the speed of access and the amount, type and scope of information accessed (Sheng and Trimi, 2008; Trimi and Sheng, 2008).

Echoing a study by Blechar et al. (2006) that explored mobile service use in Denmark it is illustrated that although participants initially felt positive in using and welcoming new mobile services; after the trial period of the services they became less favourable. A similar change in participants' attitude also occurred in terms of future mobile service intention and predictions of longer-term mobile service use. One reason for this shift in mobile phone usage perception that was identified during the evaluation stage was that the usability of mobile phones prevented the participants from using the different possibilities within the phone (Blechar et al., 2006). All the issues addressed above place usability and accessibility as top priorities for the successful implementation and wide adoption of m-Government applications.

Section 2.1 provides a brief profile of the key groups which governments need to take into account in order to promote their e-Accessibility strategy within m-Government initiatives. Although disabled people as individuals may in practice not fall easily into any one category, and may make use of a number of different assistive technologies, for the purposes of this paper we set out a framework including the following groupings: the Visually Impaired, Hearing Impaired, Motor Impaired, Speech Impaired, Cognitive Impaired and Elderly. Section 2.2 discusses the assistive technologies available for mobile devices that can be employed by these groups. 


\subsection{Disabled People}

Table 1 outlines briefly the profile of the six citizen groups that are the focus of this paper.

Due to the complex issues that define the condition of these target groups it is not possible to provide a complete profile analysis in this paper.

Table 1 - Key Groups of Disabled People (Becker, 2005; Emmanouilidou, 2005)

\begin{tabular}{|c|c|}
\hline Citizen Group & Profile Identification \\
\hline Visually Impaired & $\begin{array}{l}\text { There are three categories that fall under this group: blindness, low vision } \\
\text { and colour-blindness. The term 'legal blindness' is used to describe a } \\
\text { person's condition with a visual field of twenty degrees or less and not as } \\
\text { commonly assumed people with no vision at all. Low vision is used to } \\
\text { determine a person's vision that cannot be corrected fully with glasses. In } \\
\text { this paper the term partially sighted will be used to refer to people with } \\
\text { low vision. Colour-blind impairments fall under one of the following } \\
\text { categories: red, green, blue and achromacy. Achromacy defines people's } \\
\text { inability to see any colours, apart from black, white and shades of grey. }\end{array}$ \\
\hline Hearing Impaired & $\begin{array}{l}\text { This category includes deaf people as well as people with varying degrees } \\
\text { of hearing loss. Hearing loss can be classified as mild, moderate, severe or } \\
\text { profound. }\end{array}$ \\
\hline Motor Impaired & $\begin{array}{l}\text { There are two causes for motor impairments: i) traumatic injuries and ii) } \\
\text { diseases and congenital conditions. The first involves spinal cord injury } \\
\text { and loss or damage of limb(s), whereas the second involves among others } \\
\text { Multiple Sclerosis, Arthritis and Parkinson's disease. }\end{array}$ \\
\hline
\end{tabular}




\begin{tabular}{|c|c|}
\hline Speech Impaired & $\begin{array}{l}\text { Speech impairments can be the result of cleft lip (the incomplete joining } \\
\text { of the upper lip) or cleft palate (the abnormal passageway though the roof } \\
\text { of the mouth into the airway of the nose). Other causes i.e. Parkinson's } \\
\text { disease can also result to speech impairments. }\end{array}$ \\
\hline Cognitive Impaired & $\begin{array}{l}\text { This category includes people with Learning disabilities, Dyslexia, } \\
\text { Attention Deficit Hyperactivity Disorders (ADHD), Brain injuries and } \\
\text { Genetic diseases. }\end{array}$ \\
\hline Elderly & $\begin{array}{l}\text { Older people may present any or a combination of visual, cognitive and } \\
\text { physical impairments as part of the normal ageing process. The decline in } \\
\text { visual acuity this group may encounter can affect their ability to see } \\
\text { objects clearly, decrease their capacity to focus at close range or increase } \\
\text { their sensitivity to glare from light reflecting or shining into the eye, } \\
\text { which can impact their ability to read or distinguish objects. Because this } \\
\text { group is likely to experience a decrease in motor coordination a difficulty } \\
\text { in using a mouse, scrolling down a webpage and clicking on standard-size } \\
\text { links can be expected. The ability to discern details in the presence of } \\
\text { distracting information and perform spatial memory tasks declines as the } \\
\text { age process. This aspect is of importance if complex navigation schemes, } \\
\text { poorly designed search capabilities, and cluttered web pages are } \\
\text { introduced. }\end{array}$ \\
\hline
\end{tabular}




\subsection{Assistive Technologies for Mobile Platforms}

Subsections 2.2.1 and 2.2.2 discuss the most popular assistive technologies that disabled people make use of when viewing content via mobile devices. For the purpose of this paper mobile devices are considered visual means rather than auditory communication means. This is why the readers will find in the following subsections only the relevant affected groups (Visually Impaired - Blind, Partially Sighted, Colour Blind -, Motor Impaired, Cognitive Impaired and Elderly). The Hearing and Speech Impaired groups are not present in this discussion as their visual interaction with government applications through mobile devices does not place an accessibility challenge that will render the use of an assistive technology essential.

\subsubsection{Blind, Motor Impaired and Cognitive Impaired}

TALKS is a popular technology for blind people developed by Nuance Communications Inc., formerly known as ScanSoft, a global leader in speech and imaging solutions. TALKS converts the display text of a cell phone in highly intelligent speech. The software works with the phone's existing interface and reads aloud the text in a natural-sounding, synthesised voice. Although it was originally designed to meet the needs of the blind community other groups can also benefit, such as people with severe motor impairments, who would rather not use their hands for mobile device interaction, as well as cognitive impaired (Axistive, 2007).

\subsubsection{Partially Sighted, Colour Blind and Elderly}

Due to the reduced size of the mobile phones screen displays text and images can become unreadable. A particular technology that can be employed to overcome this issue is Nuance ZOOMS. ZOOMS is a magnifying glass, which can be used to move across the screen in order to enlarge various elements. The portion of the screen that is enlarged depends on the user's settings and the actions performed. As a user scrolls through a menu of options, 
ZOOMS can magnify each item. Users can move the magnifier on an object using key commands. When an object does not fit entirely on the screen, such as menu items, the smart scrolling feature automatically begins to scroll through the text after a brief delay. Through intelligent auto-scrolling and auto-zooming capabilities users can jump directly to areas of their interest on their cell phone. The application's Distributed Views mode can magnify all the important areas of the display at once and improve the legibility of on-screen text and graphics by allowing users to invert colour palettes or change the display to black and white, or greyscale. This last feature can be useful not only to partially sighted and older people, but also to colour blind (BusinessWire, 2005; Web Site Accessibility Blog, 2005).

\section{3 m-Government Implementations and their Use by Disabled People}

Lee et al. (2006) classify m-Government practices, based on the initiator and intensity of information exchange, into three categories: (1) Government's alert, (2) User retrieval or update and (3) Transaction. The first involves government agencies sending messages to mobile device holders with SMS being the 'killer' application. The second category allows mobile device holders to send messages to government agencies in order to request information or update records. The third, regardless of who the initiator is, involves an intensive information exchange among governments and mobile device holders via wireless networks requiring advanced data connection and synchronisation applications. This classification is employed in Table 2 to illustrate $\mathrm{m}$-Government services that the literature identifies as examples that have been implemented to specifically target disabled people (Amine and Yosra, 2005; Directgov, 2008; Rannu and Semevsky, 2005; USE-ME.GOV, no date; Zalesak, 2005). 
Of particular interest with respect to transactions is the USE-ME.GOV project. USEME.GOV (USability-drivEn open platform for MobilE GOVernment) was a project funded under the $6^{\text {th }}$ Framework Programme with the goal to "support and encourage public administrations to provide access to new e-Government services at anytime and anywhere through the use of mobile communications" (USE-ME.GOV, 2005, p.1). The project identified as a major design challenge the achievement of intuitive and efficient user interfaces for very heterogeneous use conditions. This challenge is strongly linked with the service simplicity requirement, in other words the creation of easy-to-understand and easy-touse services on mobile devices. The importance of service simplicity is underpinned by three factors: 1) infrequent use, suggesting that users will always need to be appropriately guided through the service, 2) input and output constraints (for example reduced screen size, few keys) and 3) mobile use conditions, which are typically less convenient to those available at office or home and far more distractive (USE-ME.GOV, 2005).

Table 2 - m-Government Implementations for Disabled People

\begin{tabular}{|c|c|c|}
\hline & Application & Country \\
\hline \multirow{3}{*}{ Government's } & $\begin{array}{l}\text { Hearing impaired people are notified of potential } \\
\text { dangers by the police via an SMS to a mobile device } \\
\text { that vibrates. }\end{array}$ & UK \\
\hline & $\begin{array}{l}\text { Hearing impaired people receive an SMS notification } \\
\text { in the event of an emergency, for example a fire, with } \\
\text { instructions, such as 'leave the place' or 'go home'. }\end{array}$ & $\begin{array}{l}\text { Amsterdam, } \\
\text { Netherlands }\end{array}$ \\
\hline & Disabled people can access Blue Badge information & UK \\
\hline
\end{tabular}




\begin{tabular}{|c|c|c|}
\hline \multirow{3}{*}{$\begin{array}{c}\text { User retrieval or } \\
\text { update }\end{array}$} & $\begin{array}{l}\text { (i.e. disabled parking spaces, nearby public toilets } \\
\text { and petrol stations) by texting the word 'blue' to the } \\
\text { number } 83377 \text {. }\end{array}$ & UK \\
\hline & $\begin{array}{l}\text { Hearing and/or speech impaired can send an SMS in } \\
\text { an emergency, such as a serious illness, a traffic } \\
\text { accident and so on to request help from the police. }\end{array}$ & Hong Kong \\
\hline & $\begin{array}{l}\text { Deaf people and older adults with hearing difficulties } \\
\text { can send a text message to a central police mobile } \\
\text { number to request assistance in an emergency } \\
\text { situation. }\end{array}$ & $\begin{array}{c}\text { West Midlands, } \\
\text { UK }\end{array}$ \\
\hline Transaction & $\begin{array}{l}\text { In the Health Care Information Service, one of the } \\
\text { USE-ME.GOV pilot mobile services, citizens could } \\
\text { access health related information, such as healthcare } \\
\text { prevention programmes and initiatives targeting } \\
\text { specific populations, such as the elderly and request } \\
\text { appointments at the healthcare centre according to } \\
\text { their needs (for example medical specialty) and } \\
\text { preferences (for example date and time). }\end{array}$ & Gdynia, Poland \\
\hline
\end{tabular}

\section{A Framework for Accessible m-Government Implementation}

The continuous increase in the use of mobile devices together with the latest trends for online access via such devices has pushed bodies to publish guidelines for the delivery of web content to mobile devices. The World Wide Web Consortium (W3C), an international 
consortium of academics and corporations, whose mission is to "to lead the World Wide Web to its full potential by developing protocols and guidelines that ensure long-term growth for the Web", published in July 2008 the Mobile Web Best Practices (MWBP) standard as a 'Formal Recommendation'. The aim of MWBP is to improve the overall user experience of the web when accessed through such devices (W3C, 2008a). These practices have been assembled by a number of sources, such as the Web Content Accessibility Guidelines (WCAG) 1.0, iMode Guidelines, Opera's "Making Small Devices Look Great”, Openwave Guidelines, Nokia's Series 60 XHTML-MP Guidelines, Browsing on Mobile Phones by Nokia and Little Spring Design, building on each of them to provide a definitive set of best practices for developers for the mobile web. They are therefore the most complete and detailed set of guidelines for mobile environments currently available. Following on from the widespread adoption by governments of the W3C's WCAG, for the World Wide Web, it makes sense that m-Government should also adopt the W3C's guidelines for the Mobile Web. The guidelines are grouped into five categories: 1) Overall Behaviour, 2) Navigation \& Links, 3) Page Layout \& Content, 4) Page Definition and 5) User Input (W3C, 2008b).

This section presents a technical framework for the six groups of disabled people discussed in section 2.1 based on their mobile accessibility requirements. Each requirement is linked with the relevant W3C Mobile Web Best Practice. The purpose of this framework is to contribute to government efforts to ensure that e-Accessibility is part of the design of future mGovernment applications and services.

\subsection{Visually Impaired}

Subsections 4.1.1 - 4.1.2 discuss the accessibility requirements for blind and partially sighted and colour blind people respectively. 


\subsubsection{Blind}

Blind people's main requirement is to be able to skip entire sections or navigation links in a website in order to find the information they are looking for with the least effort possible. Access keys (or keyboard shortcuts) can greatly assist the blind population while navigating within the different pages of a website. Link names must be meaningful otherwise this group will experience problems finding the desired webpage. Non-text items, such as images, must be accompanied by a text equivalent to convey the meaning of the image. Form elements (for example text boxes, check boxes and radio buttons) also require an associated label so that blind people can easily identify each box or button. Table 3 summarises these requirements.

Table 3 - Accessibility Requirements for Blind (W3C, 2008b)

\begin{tabular}{|c|c|c|c|}
\hline $\begin{array}{l}\text { Accessibility } \\
\text { Requirement }\end{array}$ & $\begin{array}{c}\text { Importance to } \\
\text { Particular Group }\end{array}$ & Can be achieved by... & $\begin{array}{l}\text { W3C Mobile } \\
\text { Web } \\
\text { Best Practice }\end{array}$ \\
\hline $\begin{array}{l}\text { Skipping content } \\
\text { and navigation } \\
\text { links. }\end{array}$ & $\begin{array}{l}\text { Blind people's assistive } \\
\text { technology will not repeat } \\
\text { 'reading aloud' any } \\
\text { unwanted information. }\end{array}$ & $\begin{array}{l}\text { Providing an 'up' link at } \\
\text { each target of the 'drill- } \\
\text { down' navigation. }\end{array}$ & $\begin{array}{c}\text { Navigation } \\
\text { Mechanisms } \\
\text { (5.2.4) }\end{array}$ \\
\hline $\begin{array}{c}\text { Providing access } \\
\text { keys. }\end{array}$ & $\begin{array}{l}\text { Blind people cannot use a } \\
\text { pointing device for } \\
\text { mobile device navigation. }\end{array}$ & $\begin{array}{l}\text { Human and Machine } \\
\text { check to verify and test } \\
\text { the use of the accesskey } \\
\text { attribute. }\end{array}$ & $\begin{array}{c}\text { Access Keys } \\
(5.2 .5)\end{array}$ \\
\hline
\end{tabular}




\begin{tabular}{|c|c|c|c|}
\hline $\begin{array}{l}\text { Providing concise } \\
\text { and descriptive } \\
\text { link names. }\end{array}$ & $\begin{array}{l}\text { Blind people can decide } \\
\text { whether to visit a link } \\
\text { when their assistive } \\
\text { technology 'reads aloud' } \\
\text { a webpage's link name. }\end{array}$ & $\begin{array}{l}\text { Human check to identify } \\
\text { non-intuitive link names, } \\
\text { such as 'click here'. }\end{array}$ & $\begin{array}{l}\text { Link Target } \\
\text { Identification } \\
\qquad(5.2 .6)\end{array}$ \\
\hline $\begin{array}{l}\text { Providing text- } \\
\text { equivalents for } \\
\text { non-text elements. }\end{array}$ & $\begin{array}{l}\text { Blind people's assistive } \\
\text { technology 'reads aloud' } \\
\text { a description for non-text } \\
\text { items (e.g. images). }\end{array}$ & $\begin{array}{l}\text { Human and Machine } \\
\text { check to verify and test } \\
\text { the use of the alt and } \\
\text { longdesc attributes. }\end{array}$ & $\begin{array}{c}\text { Non-Text Items } \\
(5.4 .5)\end{array}$ \\
\hline $\begin{array}{c}\text { Providing } \\
\text { accompanying } \\
\text { labels for form } \\
\text { controls. }\end{array}$ & $\begin{array}{l}\text { Eliminates entry errors } \\
\text { when blind people are } \\
\text { required to enter their } \\
\text { personal details in form } \\
\text { elements, such as text } \\
\text { boxes. }\end{array}$ & $\begin{array}{l}\text { Machine check to test the } \\
\text { presence of a label } \\
\text { element in form controls } \\
\text { and Human check to } \\
\text { verify whether labels are } \\
\text { properly positioned. }\end{array}$ & $\begin{array}{l}\text { Labels for Form } \\
\text { Controls } \\
\text { (5.5.3) }\end{array}$ \\
\hline
\end{tabular}

\subsubsection{Partially Sighted and Colour Blind}

Good choice of background and foreground colours is a significant requirement for both partially sighted and colour blind people. In the mobile context this issue is even more important due to the often poor colour contrast of mobile devices and the less-than-ideal lighting conditions in which these devices are used. This is also true for background images. Colour blind people to whom colour is useless, should be presented any information conveyed in colour in an alternative way. Table 4 provides an overview of these requirements. 
Table 4 - Accessibility Requirements for Partially Sighted and Colour Blind (W3C, 2008b)

\begin{tabular}{|c|c|c|c|}
\hline $\begin{array}{l}\text { Accessibility } \\
\text { Requirement }\end{array}$ & $\begin{array}{c}\text { Importance to } \\
\text { Particular Group }\end{array}$ & Can be achieved by... & $\begin{array}{l}\text { W3C Mobile } \\
\text { Web } \\
\text { Best Practice }\end{array}$ \\
\hline $\begin{array}{l}\text { Ensuring sufficient } \\
\text { contrast between } \\
\text { foreground and } \\
\text { background } \\
\text { colours. } \\
\text { Conveying } \\
\text { information in } \\
\text { colour without } \\
\text { colour. }\end{array}$ & $\begin{array}{l}\text { Inadequate contrast can } \\
\text { render the reading of } \\
\text { content difficult. } \\
\text { If form elements are } \\
\text { required to be completed } \\
\text { (e.g. 'items in red are } \\
\text { required') these should } \\
\text { be designated instead } \\
\text { using an asterisk. }\end{array}$ & $\begin{array}{l}\text { Performing human tests } \\
\text { in monochrome } \\
\text { environments and under } \\
\text { strong light conditions } \\
\text { parallel to the screen as } \\
\text { well as machine tests for } \\
\text { colour contrast via } \\
\text { automatic tools. }\end{array}$ & $\begin{array}{l}\text { Colour } \\
(5.3 .6)\end{array}$ \\
\hline $\begin{array}{l}\text { Ensuring content } \\
\text { remains readable } \\
\text { when background } \\
\text { images are used. }\end{array}$ & $\begin{array}{l}\text { Background images can } \\
\text { render the reading of } \\
\text { content difficult. }\end{array}$ & $\begin{array}{l}\text { Human check to test the } \\
\text { readability of content on } \\
\text { devices that either } \\
\text { support or not } \\
\text { background images. }\end{array}$ & $\begin{array}{c}\text { Background } \\
\text { Images } \\
\text { (5.3.7) }\end{array}$ \\
\hline
\end{tabular}

\subsection{Hearing Impaired}

Any information provided in audio format imposes accessibility barriers to people with hearing impairments. To overcome this barrier information should also be available in text 
format. Text format is suitable to those suffering from mild to moderate hearing loss, but not sufficient to those with severe hearing loss that rely on lip-reading techniques. These people require instead information to be provided in sign language. The requirements for the hearing impaired discussed here do not link to any of the W3C Mobile Web Best Practices.

\subsection{Motor Impaired}

Motor impaired people should be able to access information or perform a task with the minimum typing and scrolling possible. Typing is of particular importance to mobile devices due to the input constraints associated with these devices. Scrolling should be limited in one direction. If elements, such as maps and images on a page, require secondary scrolling then the remainder of the page must not require this too. Tables in general are not suitable for limited size screens as users may need to scroll horizontally to read them. If navigational links are included into tables then users may have to scroll both horizontally and vertically to view possible navigational choices. Table 5 further describes these points.

Table 5 - Accessibility Requirements for Motor Impaired (W3C, 2008b)

\begin{tabular}{|c|c|c|c|}
\hline Accessibility & Importance to & Can be achieved by... & W3C Mobile \\
Requirement & Particular Group & & Web \\
& & & Best Practice \\
Requiring short & Motor impaired people & Not requiring entering a & URIs of Site \\
Resource (Uniform & experience difficulties & filename or specifying a & Entry Points \\
Identifier) of site & when typing. & sub-domain as part of the & (5.2.1) \\
& & URI. & \\
\hline
\end{tabular}




\begin{tabular}{|c|c|c|c|}
\hline entry points. & & & \\
\hline $\begin{array}{l}\text { Positioning clearly } \\
\text { primary and } \\
\text { secondary } \\
\text { navigation. }\end{array}$ & $\begin{array}{l}\text { Eliminates the scrolling } \\
\text { required to access the } \\
\text { main links of a website. }\end{array}$ & $\begin{array}{c}\text { Providing primary } \\
\text { navigation at the top of } \\
\text { the page and any } \\
\text { secondary at the bottom. }\end{array}$ & $\begin{array}{c}\text { Navigation Bar } \\
(5.2 .2)\end{array}$ \\
\hline $\begin{array}{c}\text { Balancing the } \\
\text { number of } \\
\text { navigation links on } \\
\text { pages and the } \\
\text { number of links } \\
\text { required to reach } \\
\text { content. }\end{array}$ & $\begin{array}{l}\text { Eliminates the scrolling } \\
\text { required to reach } \\
\text { information. }\end{array}$ & $\begin{array}{l}\text { Providing easy reach to } \\
\text { frequently accessed } \\
\text { information with a } \\
\text { minimum number of } \\
\text { page retrievals. }\end{array}$ & $\begin{array}{l}\text { Balanced } \\
\text { Structure } \\
(5.2 .3)\end{array}$ \\
\hline $\begin{array}{c}\text { Providing access } \\
\text { keys. }\end{array}$ & $\begin{array}{l}\text { Eliminates the need to } \\
\text { scroll via a pointing } \\
\text { device. }\end{array}$ & $\begin{array}{l}\text { Human and Machine } \\
\text { check to verify and test } \\
\text { the use of the accesskey } \\
\text { attribute. }\end{array}$ & $\begin{array}{c}\text { Access Keys } \\
(5.2 .5)\end{array}$ \\
\hline $\begin{array}{l}\text { Limiting scrolling } \\
\text { to one direction. }\end{array}$ & $\begin{array}{c}\text { Eliminates the scrolling } \\
\text { required. }\end{array}$ & $\begin{array}{l}\text { Presenting images on a } \\
\text { separate page with a link } \\
\text { back to the main content } \\
\text { if images larger than the } \\
\text { screen size cannot be } \\
\text { avoided. }\end{array}$ & $\begin{array}{l}\text { Scrolling } \\
(5.3 .3)\end{array}$ \\
\hline Avoiding the use of & Eliminates the scrolling & Avoiding nested tables & Tables \\
\hline
\end{tabular}




\begin{tabular}{|c|c|c|c|}
\hline tables. & $\begin{array}{l}\text { required to read the } \\
\text { content of tables. }\end{array}$ & $\begin{array}{l}\text { and the use of tables for } \\
\text { layout and styling } \\
\text { purposes. }\end{array}$ & $(5.4 .4)$ \\
\hline $\begin{array}{l}\text { Minimizing user } \\
\text { input. }\end{array}$ & $\begin{array}{l}\text { Eliminates error entry } \\
\text { when for example filling } \\
\text { a form. }\end{array}$ & $\begin{array}{l}\text { Providing selection lists, } \\
\text { radio buttons and other } \\
\text { controls, using wherever } \\
\text { possible previous entries } \\
\text { as default values and } \\
\text { allowing item selection } \\
\text { using navigation keys } \\
\text { and/or numeric input. }\end{array}$ & $\begin{array}{l}\text { Input } \\
(5.5 .1)\end{array}$ \\
\hline
\end{tabular}

\subsection{Speech Impaired}

Accessibility barriers can occur for speech impaired people who suffer from other diseases, such as Parkinson's disease or mental retardation problems. The requirements for this group are presented in Table 6 .

Table 6 - Accessibility Requirements for Speech Impaired (W3C, 2008b)

\begin{tabular}{|c|c|c|c|}
\hline Accessibility & Importance to & Can be achieved by... & W3C Mobile \\
Requirement & Particular Group & & Web \\
& & & Best Practice \\
\hline Providing access & Speech impaired who & Human and Machine & Access Keys \\
& suffer from Parkinson's & check to verify and test & $(5.2 .5)$ \\
\hline
\end{tabular}




\begin{tabular}{|c|c|c|c|}
\hline & $\begin{array}{l}\text { disease to eliminate the } \\
\text { need to scroll via a } \\
\text { pointing device. }\end{array}$ & $\begin{array}{l}\text { the use of the accesskey } \\
\text { attribute. }\end{array}$ & \\
\hline $\begin{array}{l}\text { Providing suitable } \\
\text { error messages. }\end{array}$ & $\begin{array}{l}\text { Speech impaired with } \\
\text { mental retardation } \\
\text { problems to eliminate } \\
\text { confusion. }\end{array}$ & $\begin{array}{l}\text { Providing clear error } \\
\text { messages that indicate if } \\
\text { the issue is temporary or } \\
\text { permanent, if users can } \\
\text { solve it themselves (for } \\
\text { example by changing } \\
\text { input data or a handset } \\
\text { setting), or if the issue is } \\
\text { escalated to the content } \\
\text { provider or network } \\
\text { operator. In the latter } \\
\text { case, contact details, such } \\
\text { 'Hack', 'Retry' and/or } \\
\text { as an SMS address or a } \\
\text { support line number, } \\
\text { be provided. }\end{array}$ & $\begin{array}{c}\text { Error Messages } \\
\qquad(5.4 .13)\end{array}$ \\
\hline
\end{tabular}




\subsection{Cognitive Impaired}

This group's main requirements are clear website structure, simple language and minimum user input. The most appropriate information should be provided first and mechanisms for distinguishing information should be placed at the beginning of headings, paragraphs and lists, for contextualization purposes. Table 7 addresses these requirements in detail.

Table 7 - Accessibility Requirements for Cognitive Impaired (W3C, 2008b)

\begin{tabular}{|c|c|c|c|}
\hline $\begin{array}{l}\text { Accessibility } \\
\text { Requirement }\end{array}$ & $\begin{array}{c}\text { Importance to } \\
\text { Particular Group }\end{array}$ & Can be achieved by... & $\begin{array}{l}\text { W3C Mobile } \\
\text { Web } \\
\text { Best Practice }\end{array}$ \\
\hline $\begin{array}{l}\text { Logical } \\
\text { organisation of } \\
\text { content and use of } \\
\text { clear language. }\end{array}$ & $\begin{array}{l}\text { Can aid in efficient and } \\
\text { effective interaction with } \\
\text { the application. }\end{array}$ & $\begin{array}{l}\text { Human check to verify } \\
\text { if the content is properly } \\
\text { organised for the mobile } \\
\text { context. }\end{array}$ & $\begin{array}{l}\text { Page Content } \\
\text { (5.3.1) }\end{array}$ \\
\hline $\begin{array}{l}\text { Providing suitable } \\
\text { error messages. }\end{array}$ & $\begin{array}{l}\text { Eliminates confusion and } \\
\text { can orient users. }\end{array}$ & $\begin{array}{l}\text { Providing clear error } \\
\text { messages that indicate if } \\
\text { the issue is temporary or } \\
\text { permanent, if users can } \\
\text { solve it themselves (for } \\
\text { example by changing } \\
\text { input data or a handset } \\
\text { setting), or if the issue is } \\
\text { escalated to the content }\end{array}$ & $\begin{array}{c}\text { Error Messages } \\
\qquad(5.4 .13)\end{array}$ \\
\hline
\end{tabular}




\begin{tabular}{|c|c|c|c|}
\hline & & $\begin{array}{l}\text { provider or network } \\
\text { operator. In the latter } \\
\text { case, contact details, } \\
\text { such as an SMS address } \\
\text { or a support line } \\
\text { number, should be } \\
\text { included. 'Back', } \\
\text { 'Retry' and/or 'Home' } \\
\text { links should also be } \\
\text { provided. }\end{array}$ & \\
\hline $\begin{array}{c}\text { Minimizing user } \\
\text { input. }\end{array}$ & $\begin{array}{l}\text { Eliminates error entry } \\
\text { when for example filling } \\
\text { a form. }\end{array}$ & $\begin{array}{l}\text { Providing selection lists, } \\
\text { radio buttons and other } \\
\text { controls, using wherever } \\
\text { possible previous } \\
\text { entries as default values } \\
\text { and allowing item } \\
\text { selection using } \\
\text { navigation keys and/or } \\
\text { numeric input. }\end{array}$ & $\begin{array}{l}\text { Input } \\
(5.5 .1)\end{array}$ \\
\hline
\end{tabular}

\subsection{Elderly}

A possible combination of visual, hearing, motor, speech, and/or cognitive disabilities that this particular group may encounter together with the frequent lack of technical skills call for 
a simple, easy to use application where minimum trying and scrolling is required. Table 8 summarises the key requirements for this group.

Table 8 - Accessibility Requirements for Elderly (W3C, 2008b)

\begin{tabular}{|c|c|c|c|}
\hline $\begin{array}{l}\text { Accessibility } \\
\text { Requirement }\end{array}$ & $\begin{array}{c}\text { Importance to } \\
\text { Particular Group }\end{array}$ & Can be achieved by... & $\begin{array}{l}\text { W3C Mobile } \\
\text { Web } \\
\text { Best Practice }\end{array}$ \\
\hline $\begin{array}{l}\text { Requiring short } \\
\text { URIs of site entry } \\
\text { points. }\end{array}$ & $\begin{array}{l}\text { Older people with motor } \\
\text { impairments (e.g. } \\
\text { Parkinson's disease) } \\
\text { experience difficulties } \\
\text { when typing. }\end{array}$ & $\begin{array}{l}\text { Not requiring entering a } \\
\text { filename or specifying a } \\
\text { sub-domain as part of the } \\
\text { URI. }\end{array}$ & $\begin{array}{l}\text { URIs of Site } \\
\text { Entry Points } \\
\text { (5.2.1) }\end{array}$ \\
\hline $\begin{array}{l}\text { Positioning clearly } \\
\text { primary and } \\
\text { secondary } \\
\text { navigation. }\end{array}$ & $\begin{array}{l}\text { Older people with motor } \\
\text { impairments can access } \\
\text { the main links of a } \\
\text { website with limited } \\
\text { scrolling. }\end{array}$ & $\begin{array}{l}\text { Providing primary } \\
\text { navigation at the top of } \\
\text { the page and any } \\
\text { secondary at the bottom. }\end{array}$ & $\begin{array}{c}\text { Navigation Bar } \\
\text { (5.2.2) }\end{array}$ \\
\hline $\begin{array}{c}\text { Balancing the } \\
\text { number of } \\
\text { navigation links on } \\
\text { pages and the } \\
\text { number of links } \\
\text { required to reach }\end{array}$ & $\begin{array}{l}\text { Eliminates the scrolling } \\
\text { required to reach } \\
\text { information. }\end{array}$ & $\begin{array}{l}\text { Providing easy reach to } \\
\text { frequently accessed } \\
\text { information with a } \\
\text { minimum number of } \\
\text { page retrievals. }\end{array}$ & $\begin{array}{c}\text { Balanced } \\
\text { Structure (5.2.3) }\end{array}$ \\
\hline
\end{tabular}




\begin{tabular}{|c|c|c|c|}
\hline content. & & & \\
\hline $\begin{array}{c}\text { Providing access } \\
\text { keys. }\end{array}$ & $\begin{array}{l}\text { Eliminates the need to } \\
\text { scroll via a pointing } \\
\text { device. }\end{array}$ & $\begin{array}{l}\text { Human and Machine } \\
\text { check to verify and test } \\
\text { the use of the accesskey } \\
\text { attribute. }\end{array}$ & $\begin{array}{c}\text { Access Keys } \\
(5.2 .5)\end{array}$ \\
\hline $\begin{array}{l}\text { Limiting scrolling } \\
\text { to one direction. }\end{array}$ & $\begin{array}{l}\text { Eliminates the scrolling } \\
\text { required. }\end{array}$ & $\begin{array}{l}\text { Presenting images on a } \\
\text { separate page with a link } \\
\text { back to the main content } \\
\text { if images larger than the } \\
\text { screen size cannot be } \\
\text { avoided. }\end{array}$ & $\begin{array}{l}\text { Scrolling } \\
(5.3 .3)\end{array}$ \\
\hline $\begin{array}{l}\text { Ensuring sufficient } \\
\text { contrast between } \\
\text { foreground and } \\
\text { background } \\
\text { colours. } \\
\text { Conveying } \\
\text { information in } \\
\text { colour without } \\
\text { colour. }\end{array}$ & $\begin{array}{l}\text { Older people with visual } \\
\text { impairments to whom } \\
\text { inadequate contrast can } \\
\text { cause difficulties in } \\
\text { reading the text. } \\
\text { If form elements are } \\
\text { required to be completed } \\
\text { (e.g. 'items in red are } \\
\text { required') these should } \\
\text { be designated instead } \\
\text { using an asterisk. }\end{array}$ & $\begin{array}{l}\text { Performing human tests } \\
\text { in monochrome } \\
\text { environments and under } \\
\text { strong light conditions } \\
\text { parallel to the screen as } \\
\text { well as machine tests for } \\
\text { colour contrast via } \\
\text { automatic tools. }\end{array}$ & $\begin{array}{l}\text { Colour } \\
(5.3 .6)\end{array}$ \\
\hline Ensuring content & Background images can & Human check to test the & Background \\
\hline
\end{tabular}




\begin{tabular}{|c|c|c|c|}
\hline $\begin{array}{l}\text { remains readable } \\
\text { when background } \\
\text { images are used. }\end{array}$ & $\begin{array}{l}\text { render the reading of } \\
\text { content difficult. }\end{array}$ & $\begin{array}{l}\text { readability of content on } \\
\text { devices that either } \\
\text { support or not } \\
\text { background images. }\end{array}$ & Images (5.3.7) \\
\hline $\begin{array}{c}\text { Avoiding the use of } \\
\text { tables. }\end{array}$ & $\begin{array}{l}\text { Eliminates the scrolling } \\
\text { required to read the } \\
\text { content of tables. }\end{array}$ & $\begin{array}{l}\text { Avoiding nested tables } \\
\text { and the use of tables for } \\
\text { layout and styling } \\
\text { purposes. }\end{array}$ & $\begin{array}{l}\text { Tables } \\
(5.4 .4)\end{array}$ \\
\hline $\begin{array}{l}\text { Providing suitable } \\
\text { error messages. }\end{array}$ & $\begin{array}{l}\text { Older people who lack } \\
\text { familiarity with the use } \\
\text { of mobile technologies to } \\
\text { eliminate confusion and } \\
\text { orient them. }\end{array}$ & $\begin{array}{l}\text { Providing clear error } \\
\text { messages that indicate if } \\
\text { the issue is temporary or } \\
\text { permanent, if users can } \\
\text { solve it themselves (for } \\
\text { example by changing } \\
\text { input data or a handset } \\
\text { setting), or if the issue is } \\
\text { escalated to the content } \\
\text { provider or network } \\
\text { operator. In the latter } \\
\text { case, contact details, such } \\
\text { as an SMS address or a } \\
\text { support line number, } \\
\text { should be included. }\end{array}$ & $\begin{array}{c}\text { Error Messages } \\
\qquad(5.4 .13)\end{array}$ \\
\hline
\end{tabular}




\begin{tabular}{|c|c|c|c|}
\hline & & $\begin{array}{c}\text { ‘Back', 'Retry' and/or } \\
\text { ‘Home' links should also } \\
\text { be provided. }\end{array}$ & \\
\hline $\begin{array}{c}\text { Minimizing user } \\
\text { input. }\end{array}$ & $\begin{array}{l}\text { Older people with } \\
\text { cognitive impairments } \\
\text { and those who lack } \\
\text { familiarity with the use } \\
\text { of mobile technologies to } \\
\text { eliminate error entry } \\
\text { when for example filling } \\
\text { a form. }\end{array}$ & $\begin{array}{l}\text { Providing selection lists, } \\
\text { radio buttons and other } \\
\text { controls, using wherever } \\
\text { possible previous entries } \\
\text { as default values and } \\
\text { allowing item selection } \\
\text { using navigation keys } \\
\text { and/or numeric input. }\end{array}$ & $\begin{array}{l}\text { Input } \\
(5.5 .1)\end{array}$ \\
\hline
\end{tabular}

\section{Conclusion}

The recent developments in mobile technologies present great opportunities for governments wishing to go mobile in both the developed and the developing world. As-Saber et al. (2007) emphasise the need for a 'socio-technical' approach in e-Governance, as neither technology nor people alone can bring the success of e-Government. This is also true for m-Government. Mobile devices may have become part of our everyday lives, but they are mainly employed for personal and entertainment use, and as Verdegem and Hautekeete (2008) point out, only by specific sectors of the wider population. The accessibility challenges that elderly and disabled people can face when using mobile devices could render the realisation of valueadded m-Government very difficult indeed.

This paper has provided some insights into the accessibility requirements of key citizen groups (Visually Impaired, Hearing Impaired, Motor Impaired, Speech Impaired, Cognitive 
Impaired and Elderly) and reviewed some exemplary m-Government projects that are targeted at ensuring disabled people have access to government services. We have proposed a framework for accessible m-Government implementation as part of preliminary research in the area of socially inclusive m-Government. We have seen that the example of eGovernment, in taking the lead in promoting e-Accessibility on the Web, can be mirrored in $\mathrm{m}$-Government with the prospect that future mobile services in the private sector may take accessibility more into account than perhaps at present.

We claim that the need for the design of citizen-centric government services and the investigation of citizens' service needs as stated respectively in Kolsaker and Lee-Kelley (2007) and Shareef et al. (2009) are both important parameters for the successful technologyenabled delivery and wide embracement of any future government service. A study performed by Shareef et al. (2009) to identify the factors that influence citizens' adoption of e-Government found among others the perceived ease of use of an e-Government system to be a fundamental factor. From our review on the m-Government area and the associated challenges we have shown that this factor is also relevant to the m-Government environment. We conclude that future research should measure what Lee et al. (2006) define as 'user readiness' - the extent to which users have access to mobile devices and the user's technological competency in using mobile devices. The latter refers to the degree to which users can conduct serious activities, such as interacting formally with government, via mobile devices. Similarly, Wu et al. (2009) suggest that future research on m-Government should focus on user aspects, as well as adoption and usage patterns of mobile devices. We estimate that a thorough investigation of the user readiness of the aforementioned groups could result in much more usable and accessible m-Government applications and not only for these particular groups but for the entire population. 


\section{References}

Adam, A. and Kreps, D. (2006a) 'Enabling or Disabling Technologies?: A Critical Approach to Web Accessibility ', Information Technology and People, Vol. 19, No. 3, pp.203-218.

Adam, A. and Kreps, D. (2006b) 'Web Accessibility: A Digital Divide for the Disabled?', In: Trauth, E., Howcroft, D., Butler, T., Fitzgerald, B., DeCross, J. (eds.), IFIP International Federation for Information Processing, Social Inclusion: Societal \& Organizational Implications for Information Systems, (pp.217-228), Boston: Springer.

Amine, B. and Yosra, K. (2005) 'M-Government: The Convergence Between E-Government and Wireless Technology'. Paper Presented at the $1^{\text {st }}$ International E-Business Conference. June 23-25, 2005. Hammamet, Tunisia.

As-Saber, S., Hossain, K. and Srivastava, A. (2007) 'Technology, society and e-government: in search of an eclectic framework', Electronic Government: An International Journal, Vol. 4, No. 2, pp.156-178.

Axistive (2007). SpeechPAK TALKS for Speech-Enabled Mobile Phones. Obtained through the Internet: $\quad$ http://www.axistive.com/speechpak-talks-for-speech-enabled-mobilephones.html, [accessed 15/12/2008]

Becker, S. A. (2005) 'E-government Usability for Older Adults', Communications of the $A C M$, Vol. 48, No. 2, pp.102-104.

Blechar, J., Constantiou, I. and Damsgaard, J. (2006) 'Understanding behavioural patterns of advanced mobile service users', Electronic Government: An International Journal, Vol. 3, No. 1, pp.93-104. 
BusinessWire (2005). Nuance Introduces the Nuance Accessibility Suite; Provides Unprecedented User Accessibility to Mobile Devices. Obtained through the Internet: http://www.businesswire.com/portal/site/google/index.jsp?ndmViewId=news_view\&newsId=

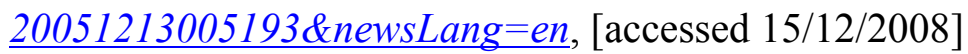

Carroll, J. (2006) 'WWhat's in It for Me?': Taking M-Government to the People'. Paper Presented at the $19^{\text {th }}$ Bled eConference eValue. June 5-7, 2006. Bled, Slovenia.

Chircu, A. M. (2008) 'E-government evaluation: towards a multidimensional framework', Electronic Government: An International Journal, Vol. 5, No. 4, pp.345-363.

Choudrie, J., Brinkman, W. P. and Pathania, R. (2007) 'Using diffusion theory to determine the digital divide in e-services: two UK local-area perspectives', Electronic Government: An International Journal, Vol. 4, No. 3, pp.345-359.

Choudrie, J., Ghinea, G. and Weerakkody, V. (2004) 'Evaluating Global e-Government Sites: A View using Web Diagnostic Tools', Electronic Journal of E-Government, Vol. 2, No. 2, pp.105-114.

Computer Economics (2007). Internet and Broadband Growth Accelerates Worldwide. Obtained through the Internet: http://www.computereconomics.com/article.cfm? id =1206, [accessed 15/12/2008]

Comscore (2007). Mobile Web Audience Already One-Fifth the Size of PC-Based Internet Audience in the U.K.. Obtained through the Internet: http://www.comscore.com/press/release.asp?press $=1432$, [accessed 15/12/2008] 
Council of Europe (2003). Council Resolution on 'eAccessibility' - improving the access of people with disabilities to the Knowledge Based Society. SOC 5. MI 4. EDUC 2. TELECOM 1.

Directgov (2008). About the Blue Badge map. Obtained through the Internet: http://www.direct.gov.uk/en/disabledpeople/motoringandtransport/dg_10038295, , [accessed $15 / 12 / 2008]$

Dwivedi, Y. K. and Williams, M. D. (2008) 'Demographic influence on UK citizens' egovernment adoption', Electronic Government: An International Journal, Vol. 5, No. 3, pp.261-274.

Emmanouilidou, M. (2005) Towards Socially Inclusive E-government. MSc thesis. Department of Computer Science, University of Manchester, Manchester, United Kingdom.

International Telecommunication Union (2008). Worldwide mobile cellular subscribers to reach 4 billion mark late 2008. Obtained through the Internet: http://www.itu.int/newsroom/press_releases/2008/29.html, [accessed 15/12/2008]

Kreps, D. (2008) 'How the Web Continues to Fail People with Disabilities'. Paper Presented at ALT-C 2008: Rethinking the Digital Divide. September 9-11, 2008. Leeds, UK.

Kreps, D. and Adam, A. (2006) 'Failing the Disabled Community?: The Continuing Problem of Web Accessibility', In: Kurniawan, S. and Zaphiris, P. (eds.), Advances in Universal Web Design, (pp.30-45), Hershey, PA, USA: IGI Global. 
Kok, A. (2009). Asian Silver Surfers Surge Online. FutureGov. Obtained through the Internet: http://www.futuregov.net/articles/2009/may/05/silver-surfers-surge-online/, _[accessed $15 / 12 / 2008]$

Kolsaker, A., Lee-Kelley, L. (2007) 'G2C e-government: modernisation of transformation?', Electronic Government: An International Journal, Vol. 4, No. 1, pp.68-75.

Kumar, M. and Sinha, O. P., (2007) 'M-Government - Mobile Technology for eGovernment', In: Bhattacharya J. (ed.), Towards Next Generation E-government, iceg'07. Obtained through the Internet: http://www.iceg.net/2007/books/2/32 343 2.pdf [accessed $15 / 12 / 2008]$

Kushchu, I. and Kuscu, H. (2003) 'From E-government to M-government: Facing the Inevitable'. Paper Presented at the European Conference on E-Government (ECEG 2003). July 3-4, 2003. Trinity College, Dublin.

Lee, S. M., Tan, X. and Trimi, S. (2006) 'M-government, from rhetoric to reality: learning from leading countries', Electronic Government: An International Journal, Vol. 3, No. 2, pp.113-126.

Loader, B.D., ed., (1998) Cyberspace Divide: Equality, Agency and Policy in the Information Society. London and New York: Routledge.

Marincu, C. and McMullin, B. (2004) 'A comparative assessment of Web accessibility and technical standards conformance in four EU states', First Monday, Vol. 9, No. 7. 
Marshall, S., Taylor, W. and You, X., eds., (2003) Closing the Digital Divide: Transforming Regional Economies and Communities with Information Technology. Westport, CT and London: Praeger.

Meyer, D. (2008). One billion PCs now is use worldwide. ZDNet.co.uk. Obtained through the Internet: $\quad$ http://news.zdnet.co.uk/hardware/0,1000000091,39437717,00.htm, [accessed $15 / 12 / 2008]$

Norris, P. (2001) Digital Divide: Civic Engagement, Information Poverty, and the Internet Worldwide, Cambridge, UK: Cambridge University Press.

Office for National Statistics (2007). Use of ICT at Home - 2 in 3 UK homes have digital TV service. Obtained through the Internet: http://www.statistics.gov.uk/cci/nugget.asp? id=1710, [accessed 15/12/2008]

Rannu, R. and Semevsky, M. (2005). Mobile Services in Tartu - Existing services, best practices, methodology and suggestions for future development. Mobi Solutions Ltd. Obtained through the Internet: http://www.ega.ee/files/Mobile\%20services\%20in\%20Tartu\%20FINAL1.pdf, [accessed $15 / 12 / 2008]$

Servon, L. J. (2002) Bridging the Digital Divide: Technology, Community and Public Policy, Malden, MA and Oxford: Blackwell.

Shareef, M. A., Kumar, U., Kumar, V. and Dwivedi, Y. K. (2009) 'Identifying critical factors for adoption of e-government', Electronic Government: An International Journal, Vol. 6, No. 1, pp.70-96. 
Sharma, S. K. and Gupta, J. N. D. (2004) 'Web services architecture for m-government: issues and challenges', Electronic Government: An International Journal, Vol. 1, No. 4, pp.462-474.

Sheng, H. and Trimi, S. (2008) 'M-government: technologies, applications and challenges', Electronic Government: An International Journal, Vol. 5, No. 1, pp.1-18.

Song, G. and Cornford, T. (2006) 'Mobile Government: Towards a Service Paradigm'. Paper Presented at the $2^{\text {nd }}$ International Conference on e-Government. October 12-13. University of Pittsburgh, Pittsburgh, USA.

Trimi, S. and Sheng, H. (2008) 'Emerging trends in M-government', Communications of the $A C M$, Vol. 51, No. 5, pp.53-58.

UNDPEPA (2002). Benchmarking E-Government - A Global Perspective. Obtained through the Internet: www.unpan.org/egovernment2.asp, [accessed 03/11/2008]

U.S. Census Bureau (2008). World POPClock Projection. Obtained through the Internet: http://www.census.gov/ipc/www/popclockworld.html, [accessed 15/12/2008]

USE-ME.GOV (no date). Gdynia - Healthcare Information. Obtained through the Internet: http://www.usemegov.org/pilot_services/gdynia.php, [accessed 05/12/2008]

USE-ME.GOV (2005). USability-drivEn open platform for MobilE GOVernment. eGovernment research in FP6 and beyond (cluster workshop), Brussels, March 1 - 2, 2005. Obtained through the Internet: $\underline{\text { http://www.usemegov.org/public- }}$ deliverables/dissemination.php, [accessed 05/12/2008] 
Verdegem, P. and Hauttekeete, L. (2008) 'The user at the centre of the development of onestop government', International Journal of Electronic Governance, Vol. 1, No. 3, pp.258274.

Vincent, J. and Harris, L. (2008) 'Effective Use of Mobile Communications in Egovernment: How do we reach the tipping point?', Information, Communication \& Society, Vol. 11, No. 3, pp.395-413.

W3C (2008a). About the World Wide Web Consortium (W3C). Obtained through the Internet: http://www.w3.org/Consortium/, [accessed 10/12/2008]

W3C (2008b). Mobile Web Best Practices 1.0. Obtained through the Internet: http://www.w3.org/TR/2008/REC-mobile-bp-20080729/, [accessed 10/12/2008]

Web Site Accessibility Blog (2005). Increased Accessibility for Mobile Devices. Obtained through the Internet: http://www.accessibilityblog.com/2005/12/20/increased-accessiblityfor-mobile-devices/, [accessed 15/12/2008]

Wu, H., Ozok, A. A., Gurses, A. P. and Wei, J. (2009) 'User aspects of electronic and mobile government: results from a review of current research', Electronic Government: An International Journal, Vol. 6, No. 3, pp.233-251.

Zalesak, M. (2005). M-Government Case Studies - SMS messages for education. SMS and Citizen M-Safety. Other interesting m-Government services. Web Projects Ltd. Obtained through the Internet: egovernment.developmentgateway.org/uploads/media/egovernment/mGov_Case_Studies.doc, [accessed 15/12/2008] 